\title{
LA COSTURERA Y EL VIENTO DE CÉSAR AIRA: LA PATAGONIA COMO CUERPO TEXTUAL
}

La costurera y el viento by César Aira: the Patagonia like textual corpus

Luciana Mellado*

\section{Resumen}

Este trabajo analiza las imágenes del espacio patagónico que pone a rodar la novela $\mathrm{La}$ costurera y el viento (1994) de César Aira, así como los procedimientos discursivos con que se construyen dichas imágenes. El libro exhibe a la Patagonia como un cuerpo textual y textualizado complejo, a través del cual se problematiza la construcción literaria de la región, como zona liminal profusa en ficciones de identidades. Desde una ostensible performatividad narrativa, la novela conjuga la invención del espacio con la frecuente referencia a una cartografía histórica y literaria que se actualiza en una dispersión de afiliaciones intertextuales.

Palabras clave: César Aira, La costurera y el viento, narrativa argentina, imágenes del espacio patagónico.

\section{Abstract}

This work analyzes the images of the Patagonian space putted on display in the novel La costurera y el viento (1994) by César Aira, as well as the discursive procedures with which these images are constructed. The book exhibits the Patagonia as a textual and textualized corpus complex, through which the literary construction of the region, as a liminal zone profuse in fictions of identities, is problematized. From an ostensible narrative performativity, the novel combines the invention of the space and the frequent reference to a historical and literary cartography updated in a dispersion of intertextual affiliations.

Key words: César Aira, La costurera y el viento, Argentine narrative, images of the Patagonian space.

\section{PRESENTACIÓN}

La costurera y el viento (1994) de César Aira cuenta, e integra, una historia de aventuras y un relato metatextual que, con insistencia, problematiza el proceso de escritura y realza los mecanismos por los cuales la fábula narra su propia invención. Este tipo de texto airano nos coloca, como observa Remón Raillard, "ante el objeto terminado que simultáneamente nos muestra cómo está siendo creado” (59). Ya en el inicio, el autor desdibuja el estatuto ficticio de su narración y refiere cómo comienza a pergeñar su historia, desde un café de París, sólo aferrado al título “La costurera y el viento”, que es el que finalmente la novela llevará.

“(H)e estado buscando un argumento para la novela que quiero escribir: una novela de aventuras, sucesiva, llena de prodigios e invenciones” sostiene el autor, al inicio del libro, enunciando los rasgos textuales que se corresponderán, en líneas generales, con los de La costurera y el viento. Sucintamente, su proposición volitiva anuncia tanto algunos componentes del texto como el modo en que éstos 


\section{Luciana Mellado}

funcionarán y se articularán. Los protagonistas son también una ocurrencia temprana, pero sus vínculos no se revelan ni imaginan de un modo contundente y unívoco. El escritor sabe que la heroína "tiene que ser una costurera, en la época en que había costureras” (7) y que será “el viento su antagonista” (7). Lo que ocurra entre ellos “(p)odría ser cualquier cosa” (7). La indeterminación de las relaciones actanciales entre ellos se extiende y disemina a todos los personajes que emprenden el viaje a la Patagonia y en esta región se transfiguran.

\section{LA PRODUCCIÓN DEL ESPACIO Y EL VIAJE}

El repertorio actoral de La costurera y el viento tiene una doble filiación. Por un lado, se presentan como figuras adjudicadas a la invención. Por otro lado, se reconocen contaminados por el pasado del autor, cuya figura emerge, tal como señalan García Díaz y Villalobos, como la del “autor ficticio” (163) de una novela en la que "el narrador construye su propia identidad como si se tratara de un personaje más de la historia” (163). Omar, el niño cuya desaparición opera como disparador de la búsqueda y aventuras que se viven en la Patagonia, se presenta como amigo de Aira, quien remonta a su propio pasado biográfico ficcionalizado, cuando tenía ocho o nueve años, la desaparición del hijo de la costurera, su vecino.

Un mediodía, arriba del acoplado de un camión, Omar y el pequeño Aira comparten "un juego puramente psicológico, de fantasía" (12), que consistía en darse miedo. Frente al terror que éste despierta, Aira cierra los ojos y cuando los abre, sin saber cómo, el hijo de Delia ya no está más allí. Inicial y equivocadamente, en el pueblo creyeron que el niño perdido era César, hasta que notan que el extraviado era Omar. Antes de narrarnos la mayúscula cadena de efectos y vicisitudes que este hecho produjo aceleradamente en la vida de un minúsculo grupo de habitantes de Pringles, el narrador ofrece un cuadro de la idiosincrasia y del modus vivendi de la sociedad del lugar, de la familia Siffoni, y de su propia familia. Según el narrador, Pringles "era un barrio, y la información circulaba rápido como un cuerpo en caída libre” (52). A través de la murmuración, el chisme y el rumor, los personajes definen y valoran a otros personajes, en "un pueblito en el que todos se conocían, y casi todos estaban más o menos emparentados” (26).

Al desaparecer su único hijo, Delia Siffoni se vuelve loca, o más loca, según palabras del narrador. Luego de varias horas de no encontrar a Omar y habiéndose ausentado Ramón Siffoni, la mujer supuso que su hijo había partido forzadamente en el acoplado del camión, hipótesis ésta que alentaron sus vecinas, quienes además "(h)icieron entonces algo absolutamente insólito: llamar un taxi, para no perder un solo minuto más y dar caza al camión” (28). Acude al llamado telefónico uno de los dos taxis que había en Pringles, el de Zaralegui, un automóvil de los que se usan “sólo para ir a la estación del Ferrocarril Roca” (29). El vehículo en cuestión era un "viejo Chrysler de los años treinta” (29).

Luego de que Delia parte hacia el sur, con la suposición de que su hijo fuera objeto de "un rapto perfectamente involuntario" (28), la narración se 
focaliza en su viaje y en los fantásticos incidentes que, ocurridos en el camino y fuera de toda linealidad, muestran que, como observa Rodríguez, "en el desierto toda recta está expuesta a los avatares de encuentros y desvíos imprevistos, a lo no-pensado” (775). La ausencia de otros vehículos circulando por el camino poceado que transitan los personajes, por ejemplo, vuelve inesperada la colisión que muchas horas después de iniciado el viaje se produce entre el taxi de Zalaregui y un camión enorme que iba delante de éste.

Las causas del choque no son claras. Quizás, plantea el narrador, el camión disminuyó un poco la velocidad, provocando una "fantástica aceleración en contra para el que venía atrás” (31). Aira reconoce que, para esclarecer este episodio, al igual que tantos otros, está "presuponiendo, con poco realismo, grandes velocidades” (2-31). A la irrealidad de la escena la completa la descripción de la conversión material de los vehículos y su unificación. El Chrysler, "reducido a un cascarón de lata retorcida" (32), se incrusta contra la parte trasera del camión y queda pegado a éste, "como un meteorito que hubiera hecho impacto en un planeta" (32). Por su parte, el camión, de aquellos que "eran realmente como planetas” (32), lo lleva a la rastra sin que el conductor, treinta metros adelante del acoplado y del choque, note siquiera el accidente. Al igual que los personajes de la novela, estos vehículos experimentan, camino al sur, una metamorfosis extrema.

En el accidente, Zaralegui, ya muerto, cae en los brazos de Delia, produciéndole a ésta tal impacto que "(p)erdió el conocimiento, y siguió viaje dormida, sin ver el paisaje” (32). El estado de inconsciencia de la costurera retrasa su vínculo con el espacio de la Patagonia y la propia constitución de este espacio puesto que el desmayo anula la mirada que constituye y organiza el paisaje. La Patagonia como lugar, como espectáculo de la naturaleza, no se instala en el relato con el ingreso de la protagonista a la región, sino mucho más tarde, un día después, luego de que el camionero que la llevaba, por el acople accidental, durmiera toda la noche y prosiguiera su marcha al amanecer, sin detenerse en todo el día siguiente. La llegada de Delia al sur es suprarreal. Al ingresar dormida, en un estado de "coma histérico" (32), la región no representa "lo real” para el personaje, ni la experiencia de un mundo exterior. Una vez anulada la percepción del recorrido que conduce a la Patagonia, el lugar se transforma, para la madre de Omar, en un inicio absoluto. Cuando ella "se despertó, el sol se ponía sobre la provincia de Santa Cruz" (32). Su llegada es total, sin imágenes previas ni familiarización progresiva o gradual con el espacio. El lugar se torna fenoménico con la recuperación de la conciencia y deviene en un escenario de intensificada percepción sensorial por parte de la costurera, para quien el mundo entonces era "( $t$ )odo el cielo rosa como el pétalo de una flor titánica, la tierra azul, un disco inmóvil sin otro límite que la línea” (33).

El narrador advierte que el territorio donde la costurera arriba accidentadamente, "por la fuerza loca de los hechos" (33), no se augura como un pasaje transitorio sino como uno irreversible, una potencial e inmensa prisión. La protagonista, sin embargo, 


\section{Luciana Mellado}

no intuye ni registra la proximidad de este destino. Lejos del desasosiego con el que partió desde Pringles, apenas llega a la Patagonia "se sintió como una niña en una calesita, montada en el lomo de un escarabajo de cristal negro. Hasta le parecía oír la música, y la oía realmente, sólo que era el silbido del viento” (33). Este momento en particular permite visibilizar una de las dislocaciones de la novela que coloca como protagonistas de la aventura a los padres del niño perdido y no a éste. El ejemplo citado muestra que, tal como observa Contreras, Delia aparece en "el lugar de la aventura infantil” (206), como una “Alicia en el país de las maravillas” (206).

Al inicial estado de ensoñación gozosa le sigue, repentinamente, el reconocimiento de la terrible circunstancia "de la que era víctima y protagonista" (33). La alusión a la doble y convergente causalidad del destino y la voluntad no le imprimen, sin embargo, un sino trágico a la historia de Delia, sino una fuerza dramática que conduce a la transmutación, y atraviesa también a los otros personajes. A la euforia que le despierta el primer contacto con el espacio, le sigue la disforia de reconocer su escabrosa situación. Espantada, al recordar lo sucedido, la costurera grita y agita los brazos con que sostenía el cadáver de Zaralegui, el que inmediatamente sale volando. Es el espacio de la Patagonia, sinecdóquicamente, el que colabora con este incidente. Al bache que "debió de haber contribuido, porque ella no tenía tanta fuerza" (33) para arrojar el cuerpo, se le suma "el torbellino del viento" (33) que impulsó hacia el aire el cuerpo muerto del taxista. Ambos elementos ejercen una fuerza performativa en los distintos avatares de la historia. El viento, cuyo protagonismo es adelantado desde el título, y el camino, que el bache presupone y distingue, se ligan connotativa y significativamente al viaje que, realizado por los personajes principales de la novela, moldea tanto el enunciado como la enunciación. La costurera y el viento es, también, el relato de un viaje.

Los caminos de la Patagonia se hacen presentes en distintos momentos de la novela, siempre en relación con la experiencia de un personaje que los transita. Con el sur como exclusiva dirección de los desplazamientos (no hay vuelta alguna hacia el norte), sus trazados y superficies incomodan, como la propia narración, el recorrido emprendido. Zarandean el taxi que lleva a la costurera rumbo a la Patagonia. Requieren de la observación cuidadosa de Zaralegui, quien, junto con Delia, iba callado y "concentrado en la conducción, que si no exigía demasiada atención por la cantidad de vehículos circulando (ninguno) sí lo hacía por lo poceado del camino" (31). Los hoyos afectan, también, la carrera de Ramón y de Silvia Balero, a quien el primero observa mantener "su posición como suspendida en el camino, como flotando encima de los pozos mientras él saltaba a más y mejor” (54). El desplazamiento por la carretera es, como el ejemplo anterior muestra, subjetivo y diferencial, pero se enmarca siempre en la desrrealización del espacio patagónico que, narrado desde la óptica de los viajeros múltiples de la novela, refiere una cartografía de un suprarrealismo hiperbólico. 
El viaje hacia el sur de la nación representa, para el pequeño universo actancial de la novela, un pasaje transformacional que involucra tan intensas modificaciones y dislocaciones que es posible hablar del ingreso a otro mundo, cuyos atributos sobresalen en la dinámica relacional que lo contrapone y articula con Pringles, el pequeño pueblo de partida. La Patagonia inmensa e imprevisible se presenta como una alteridad extrema, como un exotismo disruptivo frente a la previsibilidad pringlense, donde la lógica de la normalidad naturalizada articula las relaciones interpersonales y las somete a un conservadurismo tradicionalista centrado en el espacio interior y cerrado de cada familia y hogar. La entrada a la Patagonia significa, entonces, una iniciación y una conversión. La llegada al territorio impacta e intensifica la percepción del viajero. Al igual que Delia, el primer contacto que su marido entabla con el espacio patagónico se remite al goce contemplativo de la belleza de su paisaje. En su carrera de aceleración y desaceleración contra el pequeño auto celeste que lo seguía, Ramón Siffoni es envuelto por "el polvo transparente que se levantaba del camino de tierra” (53) y parecía "como una plata fluida” (53). El polvillo que se eleva, y rodea al personaje, visibiliza el limen atravesado y su traducción fenoménica, poéticamente descrita. Se ingresa a una atmósfera fantasmal en la que interviene, de un modo recurrente, la potencia transformadora del viento, actor y tema privilegiado de la historia que transcurre en Patagonia.

EL VIENTO: DISLOCACIONES E IRREALIDAD

La Patagonia es definida como "la tierra del viento" (33), el cual provoca que objetos y personajes tomen vuelo. Dichos vuelos son descritos a través de una sucesión de imágenes visuales en una dinámica quinésica, casi cinematográfica, que acentúa la artificiosidad de los acontecimientos y los desnaturaliza. Sus predicaciones los desplazan del plano anecdótico hacia el plano formal del texto, que tiene en el collage y la dinámica fílmica dos sobresalientes principios constructivos.

El espacio de la Patagonia se torna disruptivo en relación con los atravesados sucesiva y accidentalmente durante el viaje que la madre de Omar inicia en Pringles. Extremo y meta, el sur transgrede los límites del sentido común y ofrece resistencia a la comprensión. Mientras camina, sin saber dónde estaba ni la hora qué era, Delia se pregunta “¿Cómo era posible que siguiera siendo de día? Era de noche, eso lo sentía su cuerpo y su mente. Y aun así, era de día. ¿En qué astronomías locas había caído?” (37). Los interrogantes aluden a la transposición de la percepción, en la cual, como observa Contreras, "la transfiguración es la acción de la literatura y la Patagonia surrealista el escenario" (207). El espacio se presenta bajo el efecto de lo irreal. "Si esto es la Patagonia, ¿Yo qué soy?" (37) se interroga Delia. La espacialidad percibida se enuncia como una hipótesis posible que condiciona, como el carácter de la proposición, la definición y certidumbre de la propia identidad. La representación del paisaje repercute en la auto-representación del personaje.

Si bien las acciones de los vientos recurrentemente aludidas en la novela se hallan localizadas en la Patagonia, región que delimita su propia existencia, su 


\section{Luciana Mellado}

despliegue actancial llega a Pringles previamente al inicio de las aventuras que comienzan con la búsqueda del niño perdido, precisamente "dos o tres inviernos antes del verano en que sucede la acción de esta novela” (103). Antes de emprender uno de sus largos viajes, Chiquito hace un muñeco de nieve para el niño Aira. El muñeco, de un metro y medio de alto, modificaba su forma intensamente por causa del viento y temía derretirse cuando saliera el sol. Este miedo lo empuja a aceptar un trato con un viento que le ofrece la salvación, con la única condición de que se dejara llevar a la Patagonia, “donde el sol no derrite la nieve” (104), pero donde él sería moldeado "siempre, a cada instante" (104) por los vientos. La promesa para el muñeco es la vida eterna, a cambio de la constante metamorfosis en la que él nunca tendrá "dos veces la misma forma” (104). Una vez que el muñeco acepta al trato, del que narrador participa como testigo, el viento alza en torbellino el muñeco por los aires y se lo lleva "por el aire gris del amanecer" (104).

Este micro-relato funciona como una mise en abyme en la novela al textualizar tipos de agencias y motivos que se reiteran y proyectan en la narración en general. En primer lugar, plantea roles actanciales recurrentes a lo largo de $L a$ costurera y el viento: el de experimentante de continuas metamorfosis, el de agente promotor de las transfiguraciones, y el de testigo que observa y organiza discursivamente el relato de los hechos, siendo ocupados en la breve historia antedicha por el muñeco, el viento y el niño Aira, respectivamente. En segundo lugar, esta narración interior sitúa las actuaciones en espacios relacionales y diferenciales. Mientras los dos primeros roles se hacen efectivos en la geografía de la Patagonia, convertida en paisaje de la experiencia, el tercero sólo puede instalarse en la lejanía de los acontecimientos narrados, en el espacio de la composición textual del relato. En tercer y último lugar, el desplazamiento desde Pringles a la Patagonia se inicia bajo la modalidad volitiva y finaliza bajo la forma del destino. El viaje al sur es definitivo en dos sentidos: es irreversible para las formas de la unidad, identidad de los personajes y es espacialmente unidireccional y sin retorno. Ya no se trata, como observa Rodríguez, "de salir a Tierra Adentro, sino al Afuera de una intemperie absoluta, sin posibilidad de retorno” (775).

\section{REGIÓN Y NACIÓN: ZONAS LIMINALES Y FICCIONES DE IDENTIDAD}

Como paisaje, la Patagonia se carga de sociabilidad al enmarcarse discursivamente en los límites de una cartografía nacional. Ubicada en una posición liminar, como uno de "los más lejanos confines de la Argentina" (20), la región se incluye dentro del espacio de una polis y de una ciudadanía. La axiología de estos espacios es positiva y celebratoria. La idealización de "la maravillosa Argentina" (102-3), "hermosa como un paraíso" (63), se conjuga con la afirmación radical de una identidad nacional también celebrada. “¿Cómo vivir en otra parte? ¿No sería una locura, una autoaniquilación?” (63) se pregunta Aira, para luego responderse a sí mismo que "(n)o ser argentino es precipitarse en la nada, y eso a nadie le gusta (63)". La nacionalidad se estructura como un discurso de "lo real" sujeto al 
dispositivo ficcional de Aira que trata, tal como observa Contreras, "no de develar las falacias en las que se constituyeron las identidades nacionales (...) sino de afirmar de inmediato todo el poder de la invención, con todo el sentido afirmativo que subyace en la adopción de una ficción de identidad, y más específicamente, en la adopción imaginaria de lo que ya se es” (84).

En La costurera y el viento, la nación es un espacio que se experimenta desde el descentramiento. Estando en Francia, el narrador afirma su identidad nacional diciéndoles a los franceses, "mintiendo apenas" (27), que viene de la Patagonia. La lejanía, a la que este lugar se asocia por antonomasia, se articula con los juegos espaciales dinamizados por el relato. En la novela, las distancias son reversibles según se privilegie la óptica de la historia que narra la novela o la de la historia de la escritura de dicha novela. París es la ciudad desde la que se afirma otra ciudad. Francia es el país desde el que se afirma otro país. No se trata de un engranaje narrativo especular, de la duplicidad de escenarios, sino de un ostensivo juego de proximidades y distancias que el narrador entabla alternadamente entre el lugar enunciado y el de la enunciación. La Patagonia es, en este sentido, un procedimiento que intensifica el distanciamiento como desnaturalización perceptiva. La región está apartada de las zonas en que el autor construye su mitografía, las imágenes de su pasado y su presente, en Pringles y en París, respectivamente. El sur del país le permite acentuar el carácter no mimético ni referencial de su relato. Por lo dicho, y por la visibilidad que en la novela tiene el paisaje como artificio, podríamos afirmar que la región funciona como un escenario espectacular y exótico, invención que no constituye ni para el novelista, ni para sus interlocutores franceses, ni para sus personajes un espacio ordinario o conocido.

La Patagonia ancla su exotismo en hiperbólicas distancias y extensiones. En sus cielos, siempre limpios, se reúnen los vientos de todo el mundo, y exhiben múltiples e invisibles transformaciones. Parece que "allí sucede todo, y el resto del mundo se disuelve en la lejanía, inoperante, la China, Polonia, Egipto... París” (63).El sur del país posee, según el narrador, una centralidad gravitatoria que aleja y difumina a cualquier otro lugar del planeta. La selección de lugares enumerados que se desvanecen ante la Patagonia ejemplifica una singularidad no aleatoria. Todos ellos son espacios geoculturales fuertemente ligados a una imaginación literaria americana que, cristalizada en el modernismo, plantea la lejanía como un dispositivo de composición estética. La fuerza que ficcionaliza el locus se torna modélica y nos muestra que, tal como afirma Contreras, "uno de los mapas de la literatura de Aira es el que articula espacios canónicamente exóticos, los espacios a los que nos lleva el viaje, o el relato del viaje" (101). Sin embargo, la novela subvierte la convención de las relaciones proxémicas y representacionales de distancia, al ubicar lo lejano en una región del propio país del narrador, cuya cercanía entonces se torna ilusoria. El sur resuelve, a través de la paradoja, la oposición entre lo local y lo universal. 


\section{Luciana Mellado}

La Patagonia, planteada como artificio, subordina con su refulgencia a los otros lugares de la desmesura y los empequeñece hasta hacerlos parecer minúsculos. "La función de los lugares realmente grandes, y la Patagonia es el más grande de todos, es permitir que las cosas se hagan de veras pequeñas” (106) sostiene, aforísticamente Aira. La inmensidad de la región sería, así, el marco que posibilita la miniaturización de los objetos, no como un efecto visual escenográfico, sino como una real conversión en sus dimensiones. La Patagonia permite, por ejemplo, que París se convierta en una "miniatura lumínica" (63) y, el camión del Chiquito, el Paleomóvil, el Monstruo y el Muñeco de Nieve, gigantes que se encuentran al final de la novela, se tornen "(m)iniaturas” (106). La aparición de lo minúsculo en el universo de cosas que se confronta o entra en contacto con la descomunal Patagonia se conecta, además, con el horizonte de expectativas que despliega el cuento de la infancia, género que se entrelaza con el relato de aventuras y la narración surrealista en la novela. La medida del objeto lúdico infantil suele ser pequeña, como el "camioncito” de Ramón Siffoni, que mientras se dirigía a la Patagonia "atravesaba como un juguete los pueblos que se dormían” (49), o como el auto de Silvia Balero, de los llamados "ratones”, "un espécimen del modelo más minúsculo" (40) que se lanzó hacia la Patagonia "en la persecución más larga y peligrosa, casi como una réplica en miniatura de otra cosa, un juguete metiéndose en el mundo adulto" (40). Ese auto-juguete manipulable ingresa, como la protagonista y los otros personajes, a un mundo nuevo, fabuloso y desconocido que lo devora y descontrola. Esto advierte el narrador cuando señala que alrededor del auto de Balero, próximo al sur, "la Patagonia gigante y desierta comenzaba a abrir su bocaza” (40). La región se ofrece, con estas miniaturizaciones, como el proscenio de una maqueta que reduce y reproduce la imagen de un mundo ostensiblemente desnaturalizado.

La dilatación de la región no se describe sólo desde una perspectiva plástica, también se la presenta desde un punto de vista subjetivo, como la experiencia de lo inconmensurable y del extravío. En la Patagonia, los personajes pierden las coordenadas, desconocen su ubicación y la orientación de sus recorridos. El extravío de la costurera es señalado reiteradamente. Al enumerar a los protagonistas de la aventura, el narrador menciona a "Delia Siffoni, perdida, caminando al azar" (41). La predicación que acompaña al nombre propio especifica un atributo y una modalidad característicos del personaje situado en Patagonia. A la madre de Omar se la presenta "errando en el crepúsculo desolado" (65), yendo de un lugar a otro, sin rumbo cierto, sintiéndose "perdida, suspendida en un cansancio inhumano" (65). Al llegar la noche, se la ve "extraviada en la oscuridad, precipitándose hacia la primera forma vista con la última luz a mendigar refugio y consuelo" (66). Delia se reconoce, tal como le dice al Ventarrón, “perdida, sola, sin nada...” (79). También su esposo se extraviará en la Patagonia y andará "perdido por la meseta hiperllana, desorientado y de mal humor" (94), por la falta de costumbre de andar a pie y porque así debía desplazarse “en un desierto sin fin” (94). 
Con el repetido sintagma "la náufraga”, consignado en las páginas 47 y 67 de la novela, se define a Delia desde la gramática del viaje y se presenta indirecta e implícitamente a la Patagonia como un océano. Esta última idea, de ostensible intertextualidad con los relatos de los viajeros europeos, sitúa la historia de la protagonista en una geografía del desamparo. ${ }^{1}$ Dicha geografía, por otra parte, asume para los propios personajes la forma de lo increíble y extraordinario cuando se enfrentan a una naturaleza extraña y extrañada.

Cuando Delia, por el fuerte impulso de los vientos levanta vuelo y aterrada se aleja de la tierra, observa luego del ocaso cómo el sol vuelve a aparecer "otra vez allá en el fondo del mundo" (34). Ella "estaba en un lugar extraño" (34) cuando percibe el fenómeno inaudito de la naturaleza. Más adelante, en la historia, la rareza se desliza desde el espacio hacia al propio desplazamiento por éste. La costurera camina por la Patagonia dentro de una "lógica extraña" (45) que convierte su fatalismo discursivo en el protagonismo de su propio melodrama. A medida que pasa el tiempo, las manifestaciones de la naturaleza inaudita del sur del país dejan perpleja a Delia. La asustaban los "raros fenómenos atmosféricos" (47) que parecían acontecer en el lugar. La agitación desordenada de las nubes en el cielo y la asombrosa quietud que sobresalía en la superficie le resultaban algo "extraño, amenazante” (47) que sumado a la permanencia de la luz "se hacía escalofriante” (47) para ella.

Por su parte, Ramón también conoce y experimenta, al atravesar el Río Colorado, umbral de entrada a la Patagonia, una manifestación meteorológica excepcional, las mareas de atmósferas. El narrador explica que este fenómeno extraordinario, “muy común en la Patagonia” (50), se produce cuando la luna llena despliega "toda la fuerza de atracción de su masa sobre el paisaje” (50) y levanta y hace ondular en el aire los átomos y las partículas de la tierra, "entre ellas las de la luz y las intrincadísimas de la disposición” (50). El narrador señala que la marea de esa noche provocó dos efectos. Por un lado, le desprendió el color rojo al camión de Siffoni y lo volvió transparente, aunque, como en el vuelo de Delia, "no había nadie para verlo" (50). Por otro lado, produjo que el propio Siffoni se viera a sí mismo "como marido" (50) y advirtiera que esta condición se apoyaba totalmente en la idea de que "podría ser peor" (51). Pero mientras el extrañamiento que se produce en Ramón es pasajero, Delia experimenta en la Patagonia una rarificación perceptiva permanente. Al despertarse, luego de dormir en una incongruente cama en medio de la meseta, notó que no estaba en su casa, pero esta confusión que es común en los viajeros no fue en ella "un estado pasajero y fugaz, un pequeño lapso de desconocimiento... sino que la extrañeza se instaló en su mente como un mundo, y ahí se quedó” (83). La normalidad había quedado en Pringles, y con la entrada a

\footnotetext{
${ }^{1}$ Prieto repasa, en la introducción de Los viajeros ingleses y la emergencia de la literatura argentina 1820-1850, algunos textos de viajeros europeos que asocian las llanuras americanas con el océano. Escritos de Humboldt, en el siglo XIX, y del italiano Gervasoni y el alemán Paucke, en el siglo XVIII, ejemplifican esta difundida asociación.
} 


\section{Luciana Mellado}

la Patagonia se había perdido como los propios protagonistas y ella había ingresado a un universo alternativo e irreversible.

\section{EL ESPACIO COMO EXPERIENCIA Y PARADOJA}

Los rasgos estrambóticos del paisaje patagónico que la novela señala están sujetos principalmente a la influencia que la región tiene, misteriosamente, en los personajes y sus modos de mirar. La sola entrada a la Patagonia modifica la visión de los personajes. Ramón, por ejemplo, apenas llega a la región "se puso alucinado" (49), con "los ojos como dos estrellas" (49). Esta influencia implica en el matrimonio Siffoni, especialmente, un modo de recepción del espacio que reconoce tanto su inconmensurabilidad como su indecibilidad. La meseta que observan y recorren erráticamente los personajes es vastísima, de una dilatación hiperbólica que impide aprehenderla como totalidad. A esta dificultad se le suma otra, la de expresarla verbalmente. La Patagonia representa un "desierto bellísimo e incomunicable, en el que podrían pasar todas las aventuras” (27). Marcada por la doble imposibilidad cognoscitiva y enunciativa, la región participa de otra paradoja, la de ser un lugar simultáneamente abierto y cerrado.

A pesar de la apertura de la inmensa superficie de la naturaleza patagónica, el territorio se transforma en una cárcel para los personajes. La novela no sólo no narra el regreso de ninguno de los viajeros pringlenses sino que sugiere de modo insistente que ellos no saldrán nunca de allí. Se apunta la improbabilidad de marcharse del lugar, por ejemplo, cuando el narrador observa que "parecía totalmente impensable que fuera a salir alguna vez" (33) la costurera de la Patagonia. Ella misma piensa, desesperadamente: “¡Nunca volveré a Pringles!” (88). Pero no sólo los personajes no podrán volver a su hogar, sino que en algunos casos perderán, de modo irrecuperable, los medios de transporte con que ingresaron al lugar y con los que podrían egresar de él. El Chrysler de Zaralegui con el que Delia llegó a la Patagonia se destruyó en un colosal choque contra el camión de Chiquito en cuya parte trasera quedó incrustado. El camioncito de Ramón, con el que arriba al sur, no sirve más porque, tal como le informa Ventarrón a Delia, "se hizo invisible y nadie volverá a conducirlo nunca" (88). La Patagonia se vuelve, por las circunstancias narradas, irreversible. Nadie vuelve de allí. La resistencia y las dificultades del espacio que se describen en la novela se reiteran en la novela de la novela, donde Aira adulto, en un ejercicio de constante indagación metaliteraria, reflexiona, entre otras cosas, sobre la gente que sueña con viajar a la Patagonia. Señala que

“(t)odos están más o menos resignados a no llegar nunca tan lejos, y en eso debo darles la razón. ¿Qué irían a hacer allá? Y además, ¿Cómo llegar? Se interponen todos los mares y ciudades, todo el tiempo, todas las aventuras. Es cierto que hoy las compañías de turismo simplifican mucho los viajes, pero por alguna razón sigo pensando que ir a la Patagonia no es tan fácil. Lo veo como algo distinto de cualquier otro viaje” (27). 
Si la lejanía es siempre un significado relacional y relativo al punto de vista y al locus de enunciación, en la resemantización que propone la novela, su significado se vuelve totalizante y extremo, como la propia región. La Patagonia está lejos de todo y de todos. Su dificultad deja de ser relativa y pasa a ser inherente, una propiedad del lugar que se singulariza, a la vez que añade al territorio la dimensión necesaria para ubicar las peripecias de la acción en el espacio simbólico de una aventura. La Patagonia, además, se instala como el destino de un viaje, de un desplazamiento que es, en la novela, unidireccional. Los personajes marchan hacia el sur del país sin poder realizar el viaje de retorno, como ya dijimos. Lugar de paso que se convierte finalmente en el lugar de lo ineludible, la región no sólo no representa el domicilio propio, el hábitat de los personajes, sino que carece, en la novela, de una población propia. El único personaje que reside en la región y actúa en la historia es el viento.

El viento singular, no la masa uniforme de vientos sin habla y de exclusiva existencia natural que aparece en la novela, se llama Ventarrón. Su figura antropomorfizada se caracteriza desde un doble perfil actancial y discursivo. En la acción narrativa se desempeña predominantemente como un ayudante actancial de Delia, salvándola de los vientos que jugaban con ella en el cielo, ayudándola a escaparse de la furia de Chiquito, e intentando defenderla del Monstruo. Sus actos discursivos también se definen en relación con la costurera, único personaje al que le habla y con quien dialoga a lo largo de la historia. ${ }^{2}$ Le promete a Delia protegerla y complacerla en sus deseos, le informa de la existencia del peligro encarnado en el Monstruo y la consuela. Su enunciación, modelada desde una exacerbada galantería, no llega a plasmarse en la forma de una confesión amorosa. Son precisamente estas palabras no dichas las que se meten "en los intersticios de la Patagonia" (91), para luego dar paso, "en una superposición de capas de ficción (ficción sobre ficción)” (Contreras 208), a la leyenda de La costurera y el viento.

\section{LA PATAGONIA COMO CORPUS TEXTUAL}

La Patagonia no es sólo el escenario donde acontecen estos hechos extraordinarios, una especie de contenedor incontaminado de lo fantástico, sino, por lo contrario, un lugar cuya propia existencia es legendaria, tanto por la deriva metonímica que condensa Ventarrón, como por la predestinación que lo une a otra leyenda, la "que dice que un día va a nacer, en un hotel termal de la zona, un niño dotado de todo el poder de las transformaciones, un ser que será la cápsula de todos los vientos del mundo, el molde del viento, por lo tanto feo hasta el espanto" (85). El Monstruo, cuyo poder se funda en la "anterioridad a la forma” es el niño que nació antes de tiempo: antes de estar completamente

\footnotetext{
${ }^{2}$ Sobre el movimiento de la conversación en Aira, véase Contreras, Sandra. "César Aira: El movimiento de la idea”. En Boletín /4. Abril de 1995. Rosario: Universidad de Rosario. 45-64.
} 


\section{Luciana Mellado}

formado” (Contreras 206), comparte con la Patagonia, su lugar de nacimiento, la facultad y la fuerza aterradora de las mutaciones. ${ }^{3}$

La irrealidad de la Patagonia de las leyendas convive con una existencia que la narración ubica en el plano empírico. Río Colorado, Río Negro, Santa Cruz, Esquel, Comodoro Rivadavia son los topónimos mencionados en la novela que dan cuenta del anclaje referencial de la cartografía representada. Los nombres propios de los lugares no señalan solo una localización sino fundamentalmente un recorrido, el dibujo de un itinerario que nunca se derrama fuera del mapa de la nación. Hasta los vientos que atraviesan la región, las masas de aire que allí se desplazan, participan indefectiblemente de esta cartografía de la patria. Todos los distintos vientos, los "cosmopolitas y oceánicos tanto como los diminutos soplos de jardín” (62) terminan reuniéndose siempre "en los cielos argentinos" (62) y más específicamente, en "esa región privilegiada de la atmósfera que es la Patagonia” (62). La región se imagina desde los límites políticos administrativos de la nación, aunque el narrador advierta que no está "hablando en metáforas patrióticas" (63), y que lo narrado "es real” (63). El sur se expresa como una sinécdoque de la cartografía nacional, ligada a las narraciones fundacionales que, desde fuera de esa comunidad imaginada, la refirieron y relataron.

La Patagonia se describe como el lugar de la excepción, ya textualizado. “(E)l instante, que en cualquier parte es seco y fijo como un clic, en la Patagonia es fluido, misterioso, novelesco. Darwin lo llamó: la Evolución. Hudson: la Atención” (63), sostiene el narrador. La predicación visibiliza la perspectiva narrativa de la novela, el enfoque del viajero foráneo que encuentra un apasionante exotismo liminar en la Patagonia. Más específicamente, y como afirma Contreras, La costurera y el viento, ya instalada en el siglo XX, "se encara desde el punto de vista del viajero inglés" (101). Además de evidenciar un sistema de afiliaciones discursivas de la novela, las figuras de Darwin y Hudson son claves en la construcción del corpus literario referido a la Patagonia. Ambos escritores no sólo difundieron, a través de sus escritos, una versión hegemónica de la región, sino que la dieron a conocer a la comunidad nacional e internacional. Tal como Prieto recuerda, al incorporar en sus textos al inmenso territorio patagónico, "Darwin construye en su diario una imagen de la Argentina más abarcadora y compleja de la que muchos de los propios argentinos tenían del país entre los años 1835 y 1845” (105). Por su parte, Hudson vuelve, en

\footnotetext{
${ }^{3}$ El Monstruo de la novela trasciende los límites del texto y se presenta también como el Monstruo arltiano. Al respecto, Contreras señala que "cuando el Viento le cuenta a la Costurera la leyenda del Niño Monstruo” del niño que no debió nacer, feo hasta el espanto e impulsando todas las deformaciones - la réplica de la Costurera (¿Pero de dónde pudo salir ese monstruo?) reproduce la célebre pregunta de Erdosain en Los Lanzallamas (¿De dónde habrán salido tantos monstruos?). Además, centrada en rigor en torno al nacimiento del Monstruo (Fue así como vino al mundo el Monstruo), la leyenda de La Costurera y el Viento se vincula directamente con "la novela del Monstruo" con la que Aira cuenta — inventa — la genealogía de "la novela de Arlt” (Las vueltas, 231).
} 
Idle Days in Patagonia (1893), hacia la naturaleza patagónica, desplaza el viaje a la región "de la historia para inscribirlo en la autobiografía” (Livon-Grosman, 183) e inaugura una etapa de metaforización del territorio que se extiende a otras producciones nacionales y extranjeras durante el siglo XX. ${ }^{4}$ Varios son los aspectos de la novela que hacen ostensible un juego de relaciones intertextuales con los textos referidos a la Patagonia de estos dos escritores. "Días de ocio en la Patagonia", por ejemplo, es una expresión que se repite y cita el libro homónimo de Hudson, del que también se recupera, de un modo más general, la noción de la experiencia de la naturaleza, concebida como wilderness. ${ }^{5}$ Por otro lado, el narrador también retoma, como se ejemplificó más atrás, dos aspectos que Darwin atribuye a la Patagonia: su vacío y su ilimitación. ${ }^{6}$ Para los personajes pringlenses en la Patagonia no hay nadie más allá que ellos mismos, desamparados, ni nada más que la búsqueda de un mundo pretérito que no podrán recuperar en la región de las transformaciones.

La distancia existente entre el locus de enunciación y el territorio narrado es otro elemento compartido por el narrador de la novela con estos viajeros. El autor de La costurera y el viento escribe, al igual que los autores antedichos, desde la perspectiva europea, en su caso desde un café de París, sobre los límites del mundo. Sin embargo, esta distancia no opera en la novela de Aira como un dispositivo monofónico y vertical desde el cual se pretende definir una alteridad, sino más bien como un recordatorio constante del carácter inventivo y novelesco del aparato narrativo. El montaje de dicho aparato singulariza las distintas aventuras referidas y se desembaraza del anclaje histórico referencial sobre la región desde el momento en que el autor afirma: “Apoderarse del olvido es poco más que un gesto, pero sería un gesto consecuente con mi teoría de la literatura, al menos con mi desprecio por la memoria como instrumento del escritor" (8). El relato de viajes, además, se ofrece como una matriz genérica del relato que no agota su organización. La costurera y el viento no narra el viaje sucesivo que un único héroe realiza, sino un viaje con múltiples protagonistas y perspectivas que le suma a la complejidad del repertorio

\footnotetext{
${ }^{4}$ Livon Grosman explica que Hudson extiende la metaforización del territorio "a otros escritores de habla inglesa que habrán de visitar la Patagonia en la segunda mitad del siglo XX, como es el caso de Paul Theroux o Bruce Chatwin, y estos a su vez serán el punto de partida para nuevas narrativas argentinas” (15).

${ }^{5}$ Livon Grosman señala que en Idle Days in Patagonia, Hudson se refiere a la naturaleza con el término wilderness, palabra usualmente traducida como "naturaleza", pero que inglés tiene una significación distinta que "nature". Recuerda entonces que el Diccionario de Inglés de Oxford (OED) define wilderness como: "algo pensado como una región de carácter salvaje o desolado, o en la cual uno merodea o en la que extravía su camino; en un sentido religioso se aplica a este mundo o esta vida como contraste con el cielo o con una vida futura” (185-6).

${ }^{6}$ En Journal and Remarks, Darwin sostiene que las extensiones patagónicas "pueden ser solamente descriptas por caracteres negativos: sin habitantes, sin agua, sin árboles, sin montañas" y afirma también que "(l)as llanuras de la Patagonia no tienen límites, porque son difícilmente atravesables, y en consecuencia desconocidas” (Prieto, 104).
} 


\section{Luciana Mellado}

actoral una temporalidad y espacialidad que también se desarrollan profusa y simultáneamente.

Universidad Nacional de la Patagonia San Juan Bosco* Facultad de Humanidades y Ciencias Sociales

Ciudad Universitaria. Ruta 1. Km. 4 Comodoro Rivadavia. Chubut. C.P. 9005 (Argentina) lucianamellado@infovia.com.ar

BIBLIOGRAFÍA

Aira, Cesar. La costurera y el viento. México DF: Ediciones Era, 2007.

Contreras, Sandra. Las vueltas de César Aira. Rosario: Beatriz Viterbo, 2008.

------- “César Aira: el movimiento de la idea”. Boletín /4 del Grupo de Estudios de Teoría Literaria, UNR, Abril de 1995:45-64.

Livon-Grosman, Ernesto. Geografías imaginarias. El relato del viaje y la construcción del espacio patagónico. Rosario: Beatriz Viterbo, 2003.

Prieto, Adolfo. Los viajeros ingleses y la emergencia de la literatura argentina 1820-1850. Buenos Aires: F. C. E., 2003.

Rodríguez, Fermín. "Movimientos literarios de fines de siglo. Sobre la literatura de fronteras de César Aira”. AAVV. Fin(es) de siglo y Modernismo. (Congreso Internacional Buenos Aires, La Plata 1996. Vol. II): Editado por Universitat de les Illies Balears, 2001:773-779.

Remón Raillard, Margarita. "La narrativa de César Aira: una sorpresa continua e ininterrumpida”. Geneviève Fabry, Ilse Logie. La literatura argentina de los noventa. Foro Hispánico 24. 53-64.

Villalobos, J. Pablo; García Díaz Teresa. "Para leer a César Aira”. AA.VV. Cesar Aira en miniatura: un acercamiento crítico. Veracruz, México: Universidad Veracruzana, 2006:141-168. 